\title{
経尿道バルーン・レーザー治療による犬前立腺 組織内温度分布の検討
}

\author{
群馬大学医学部泌尿器科学教室（主任：山中英寿教授） \\ 黒川 公平 鈴木 孝憲 鈴木 和浩 山中 英寿
}

\section{INTERSTITIAL TEMPERATURE MEASUREMENT DURING BALLOON LASERTHERAPY (PROSTALASE $^{\mathrm{TM}}$ ) OF THE CANINE PROSTATE}

\author{
Kohei Kurokawa, Takanori Suzuki, Kazuhiro Suzuki and Hidetoshi Yamanaka \\ Department of Urology, Gunma University School of Medicine
}

(Director: Prof. Hidetoshi Yamanaka)

We examined the distribution of interstitial temperatures during balloon lasertherapy, using 4 mongrel canines. The laser equipment (CL50FS, SLT Japan Co. Ltd. Tokyo, Japan) consisted of $\mathrm{Nd}$ :YAG laser that produced 360 spindle-shaped radiation from a laser balloon (2 $\mathrm{cm}$ long) with a water-cooled circulation system. By measuring the temperature $3 \sim 5$ minutes after the beginning of the treatment, we obtained following results.

The temperature of the bladder neck and urethral sphincter remained below $42^{\circ} \mathrm{C}$ except under extreme conditions. The temperature at a $6 \mathrm{~mm}$ depth from the prostatic urethra rose as laser energy increased, but was not affected by increased circulation of cooling water. The temperature at a $10 \mathrm{~mm}$ depth from the prostatic urethra was not affected by either increased laser energy or increased circulation of cooling water. We concluded that the limit of tissue cooling is within $6 \mathrm{~mm}$ and direct transmission of laser energy is within $10 \mathrm{~mm}$.

Distribution of the tissue temperature peaked at a $6 \mathrm{~mm}$ depth in the prostatic urethra. When cooling water was circulated at a $200 \mathrm{ml} / \mathrm{min}$ and laser-energy was generated at $30 \mathrm{~W}$, the temperature distribution demonstrated that at a $4 \sim 10 \mathrm{~mm}$ depth from the prostatic urethra reached over $45^{\circ} \mathrm{C}$ and at a $6 \mathrm{~mm}$ depth from the prostatic urethra, a peak of $52^{\circ} \mathrm{C}$ was obtained. The possibility of thermotherapy of the prostate was suggested.

Key words: laser treatment of the prostate, temperature distribution of the tissue

要旨：経尿道バルーン・レーザー治療における組織内温度分布を知る目的で，雑種雄犬 4 頭を用いて前 立腺治療における組織内温度を測定した。照射装置として Nd：YAGレーザーによる, 360度照射可能な 灌流式レーザー・バルーンを用いた，条件として，4 ${ }^{\circ} \mathrm{C}$ の冷却水を流速を $100 \mathrm{ml} / \mathrm{min}, 200 \mathrm{ml} / \mathrm{min}$ およ び $300 \mathrm{ml} / \mathrm{min}$ とし, 各々の流速に対して出力を $15 \mathrm{~W}, 30 \mathrm{~W}$ おび $50 \mathrm{~W}$ とし以下の各点で治療開始 $3 \sim 5$ 分後の温度測定を行った. 温度測定部位は, 膀胱頸部, 尿道括約筋部, 前立腺尿道粘膜より $2 \mathrm{~mm}, 4 \mathrm{~mm}$, $6 \mathrm{~mm}, 10 \mathrm{~mm}$ の深さの前立腺組織内および直腸粘膜の 7 点であった。この検討により次の結果が得られ た. 膀胱頸部, 尿道括約筋部は極端な条件を除けば $42^{\circ} \mathrm{C}$ 以下に保たれた. $6 \mathrm{~mm}$ の深さの前立腺組織内温 度はレーザー出力の上昇とともに上昇したが, 同一出力では冷却水の流速によらず一定であった. $10 \mathrm{~mm}$ の深さの前立腺組織内温度は, レーザーの出力の上昇によらずほほ一定であった．以上より，組織の冷 却効果の深達度は $6 \mathrm{~mm}$ 以内であり, レーザー・エネルギーによる直接的な加温は $10 \mathrm{~mm}$ 以内と考えられ た. また，治療開始直後の前立腺内組織温度は $6 \mathrm{~mm}$ の深さがピークとなる一峰性の分布をとった. 出力 $30 \mathrm{~W}$, 流速 $200 \mathrm{ml} / \mathrm{min}$ の条件でピーク温度が平均 $52^{\circ} \mathrm{C}$ とり, $4 \sim 10 \mathrm{~mm}$ の前立腺組織内温度は $45^{\circ} \mathrm{C}$ 以上 に保たれた。前立腺高温度治療の可能性が示唆された。 
キーワード : 犬前立腺, レーザー治療, 組織内温度分布

\section{緒 言}

前立腺肥大症 (以下 $\mathrm{BPH}$ ) の治療においては, 経尿 道的切除 (以下 TURP) が“gold standard”として広く 普及している.しかし, 最近, 米国において高齢化社 会が急速に進行し TURP の増加が健康保険システム を圧迫しているとの報告 ${ }^{1}$ や, 症状の軽い $\mathrm{BPH}$ に対す る TURP は必ずしも有効ではない2)との報告がなさ れた。このためか, BPH に対するより侵襲の少ない治 療法が注目され臨床に導入されつつある ${ }^{3) \sim 5)}$.

レーザーの BPH 治療への応用は，この種の治療の 一つであるが臨床応用されて日が浅いため, 充分な データが蓄積されるには至っていない(6)7).

われわれはバルーン・レーザーを用いて, 犬前立腺 の治療を行いその結果を報告してきた ${ }^{8) 9}$. 今回は, 尿 道粘膜を温存した前立腺高温度治療の可能性を知る目 的で, 雑種犬を対象に種々の条件下で, レーザー治療 時の前立腺組織内温度測定を行ったのでこの結果につ き報告する。

\section{対象および方法}

対象として雑種雄犬 4 頭 (平均体重 $14 \mathrm{~kg}$ ) を用いた。 全例治療前に会陰瘦を作成しておいた。前立腺サイズ は, エコー計測上平均 $9.7 \mathrm{~cm}^{3}$ であった. 以下の治療は, すべて全身麻酔下に行った。さらに，動物の取扱いは 当大学医学部附属実験施設の規則を遵守して行った。

レーザー発生装置はSLT ジャパン社製 CL50FS (Nd: YAG レーザー, 波長1,065nm, 連続波)であり， 照射装置としては 360 度照射可能な灌流式レーザー・バ ルーン（長さ $2 \mathrm{~cm}$ )を用いた。このバルーンよりのレー ザー分布は，横断面では同芯円状，縦断画では楕円状 となることが知られている。このバルーンには，3 組 の熱電対が取り付けられており膀胱頸部 $(\mathrm{TBn})$, バ ルーン表面（Ts）および尿道括約筋部（TSp）の温度 測定が可能であり，またバルーン内を冷却水が灌流す る構造になっている，使用した熱電対は TYPE K (安 立計器製, JIS 0.75級) のものであり, 使用温度限界 は $200^{\circ} \mathrm{C}$, 実測 $43^{\circ} \mathrm{C} 43 \pm 0.1^{\circ} \mathrm{C}$ 以内に表示される。

ペントバルビタール $(25 \mathrm{mg} / \mathrm{kg})$ による全身麻酔下 に犬を仰臥位とし，用指的に直腸内の糞塊を十分に除 去した。次に経直腸的エコー（東芝社製，SAL-77B， PVL516S) による前立腺観察の後, 以下のごとく前立 腺組織内への熱電対挿入を行った。横断エコーを併用 しつつ縦断エコー下に, 前立腺左葉尖部, 尿道粘膜よ
図 1 実験のシェーマ. TBn：膀胱頸部温度. TSp : 尿道括約筋部温度. T2, T4, T $6, \mathrm{~T} 10$ : 尿道粘膜上 り各深さに扔ける前立腺組織内温度. TRec：直腸 粘膜温度.

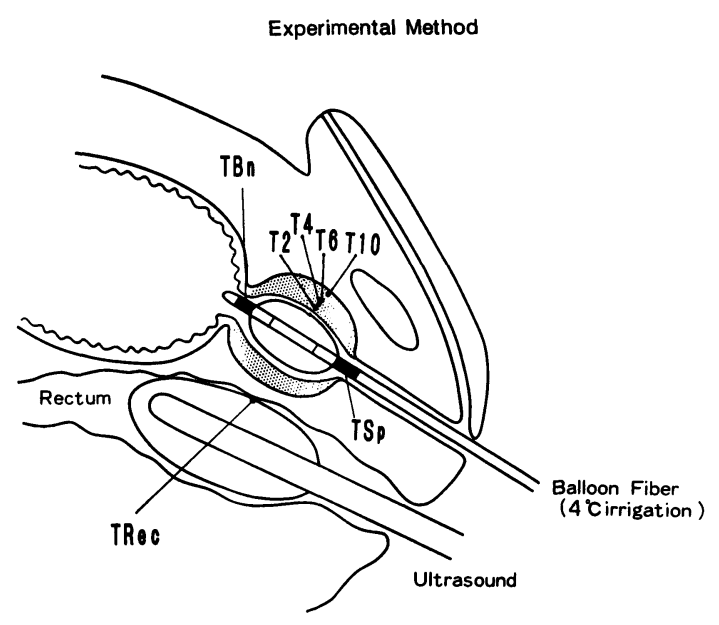

り約 $2 \mathrm{~mm}$ の深さに18ゲージ針(長さ $11 \mathrm{~cm})$ を経会陰的 に挿入した。この18ゲージ針を通して，同様なエコー 下に熱電対を前立腺中央部（膀胱頸部と尖部の中間） 左葉の尿道粘膜より $2 \mathrm{~mm}$ の深さの部位に挿入した。そ の後会陰瘦より前立腺部尿道にレーザー・バルーンを 留置し径 $1 \mathrm{~cm}$ に水で膨らまし, バルーン表面と熱電対 の距離をエコーにて再測定した。その值が2 $\mathrm{mm}$ となる まで手技を繰り返した（T2）。同様な手技により $4 \mathrm{~mm}$ (T4)，6mm（T6）および10mm（T10）に熱電対を挿 入した（図 1 ).

可変条件として $4{ }^{\circ} \mathrm{C}$ 冷却水の流速およびレー ザー・エネルギー出力をとり, 流速 $100 \mathrm{ml} / \mathrm{min}, 200 \mathrm{ml} /$ $\min お$ おび $300 \mathrm{ml} / \mathrm{min}$ の各条件下で，出力を $15 \mathrm{~W}, 30$ $\mathrm{W}$ および $50 \mathrm{~W}$ とした.治療関始 $3 \sim 5$ 分後(T6がほほ 一定となる時期）の各温度を計測した。温度測定部位 は前述の TBn，TSp，T2，T4，T6，T10および直腸 粘膜 (TRec) の 7 部位であった。 4 頭すべてにおいて, $15 \mathrm{~W}$, 流速 $300 \mathrm{ml} / \mathrm{min}$ の最も穏やかな条件から順に測 定し, 最後に $50 \mathrm{~W}$, 流速 $100 \mathrm{ml} / \mathrm{min}$ の最も強い条件で の測定を行った。

\section{結 果}

表 1 に出力 $15 \mathrm{~W}, 30 \mathrm{~W}$ および $50 \mathrm{~W}$ における, 冷却水 の流速と TBn および $\mathrm{TSp}$ の平均温度と標準偏差を 示した。これらの温度は $50 \mathrm{~W}$, 流速 $100 \mathrm{ml} / \mathrm{min}$ および 
表 1 各条件での膀胱頝部および尿道括約筋部の平均温度

\begin{tabular}{c|ccc|ccc|ccc}
\hline 出力 $(\mathrm{W})$ & \multicolumn{3}{|c|}{15} & \multicolumn{3}{c|}{30} & \multicolumn{3}{|c}{50} \\
\hline 速度 $(\mathrm{ml} / \mathrm{min})$ & 100 & 200 & 300 & 100 & 200 & 300 & 100 & 200 & 300 \\
\hline 膀胱頝部 & 34.4 & 33.3 & 33.1 & 40.6 & 40.5 & 41.2 & 45.1 & 44.7 & 41.8 \\
& 0.23 & 0.26 & 0.31 & 0.28 & 0.35 & 0.26 & 0.34 & 0.33 & 0.36 \\
括約筋部 & 27.0 & 26.3 & 25.4 & 29.1 & 29.7 & 28.4 & 42.4 & 40.9 & 41.5 \\
& 0.21 & 0.25 & 0.29 & 0.21 & 0.32 & 0.27 & 0.36 & 0.31 & 0.30 \\
\hline
\end{tabular}

上段：平均温度 $\left({ }^{\circ} \mathrm{C}\right)$ 下段：標準偏差

図 2 各部位の温度変化. 横軸に出力を取り冷却水の流速により分けた.
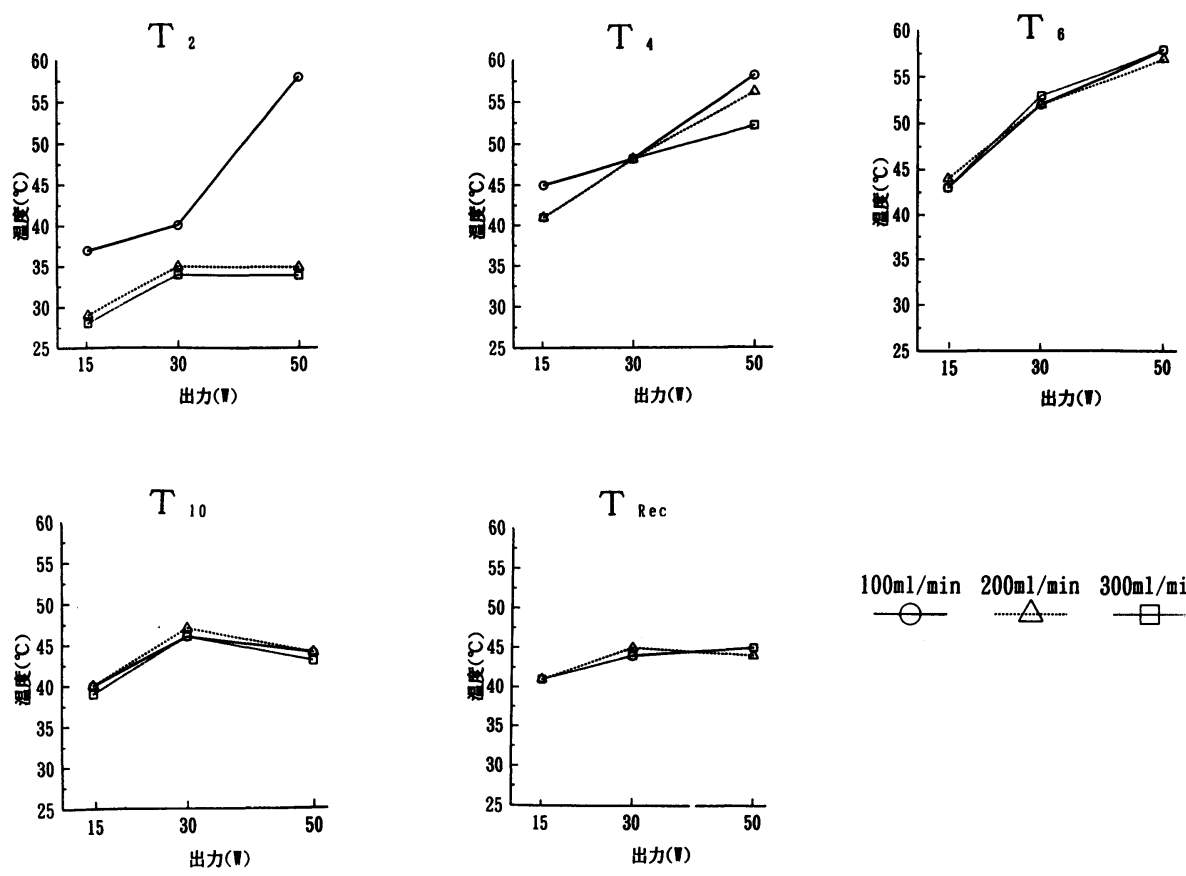

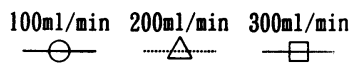

$200 \mathrm{ml} / \mathrm{mis}$ の極端な条件を除けば平均 $42^{\circ} \mathrm{C}$ 以内に保 たれていた。

図 2 に横軸に出力をとった場合の各部位の温度変化 を流速により分けて示した. T2では流速が大きい場合 明らかではないが，T4および $\mathrm{T} 6$ では出力の上昇にと もなって温度上昇がみられた。しかし，T10および $\mathrm{TRec}$ では出力が上昇しても明らかな温度上昇は認め られなかった。

図 3 に横軸に流速をとつた場合の各部位の温度変化 を出力により分けて示した. T2では流速の増加ととも に，温度が下降する傾向を示した，T6では流速が増加 しても温度の下降傾向はみられなかった. T4はこの中 間に属した。

図 4 に各流速における温度分布を, 横軸に温度測定
部位をとり出力により分けて示した。各流速で $\mathrm{T} 6$ が ピークとなる温度分布を示した. 出力 $30 \mathrm{~W}$, 流速 200 $\mathrm{ml} / \mathrm{min}$ の条件でピーク温度が平均 $52^{\circ} \mathrm{C}$ とり, $4 \sim 10$ $\mathrm{mm}$ の前立腺組織内温度が $45^{\circ} \mathrm{C}$ 以上に保たれた。

\section{考察}

より侵襲の少ない治療の一つとして, ハイパーサー ミアあるいは高温度治療が BPH の治療手段として普 及しつつある3 ${ }^{35)}$.このような治療においては, thermal damage のおよぶ範囲および程度を正確に評価するこ とが重要である。このためには種々の治療条件におけ る温度分布の状態, および治療温度 X 治療時間による 組織の病理学的変化を知らなければならない. 後者に ついては, 共著者鈴木が既に報告を行った ${ }^{9)}$. 本報告で は前者につき若干の検討を加えた。現在までにレー 
図 3 各部位の温度変化. 横軸に流速を取り出力により分けた。
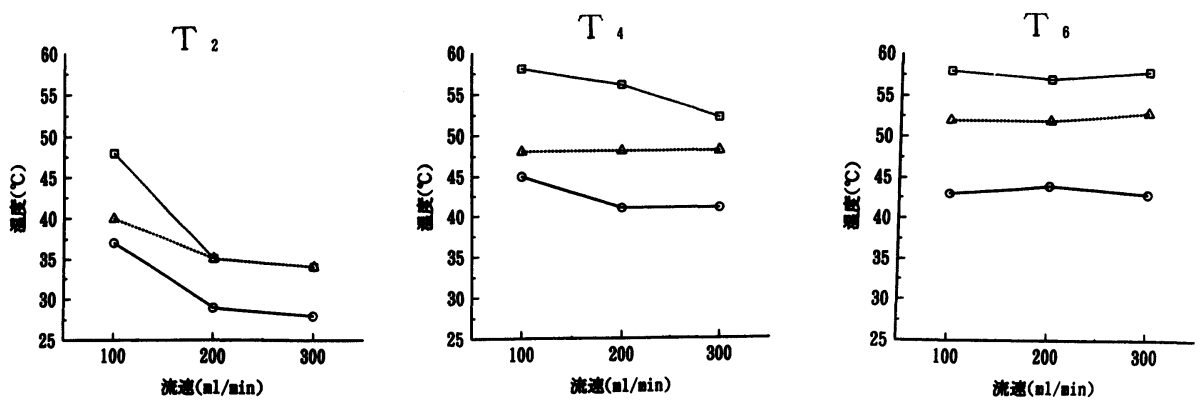

$T_{10}$

$T_{\text {Rec }}$
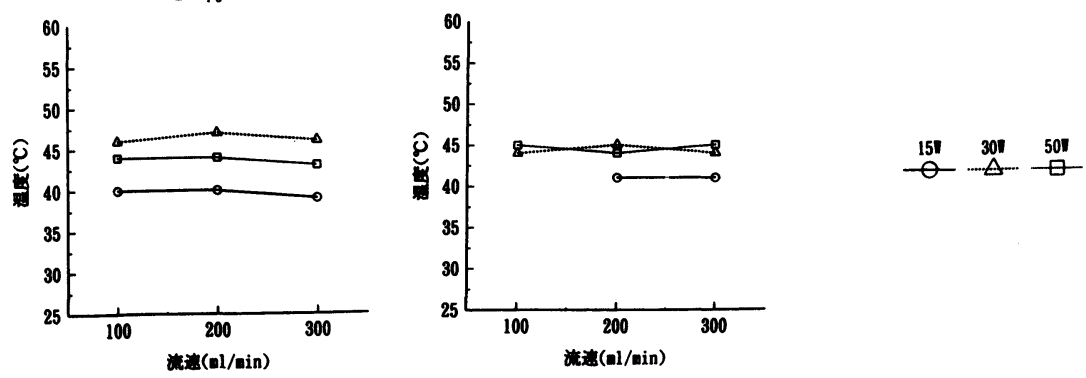

図 4 各流速毎の温度分布. 出力により分けた。

$100 \mathrm{ml} / \mathrm{min}$

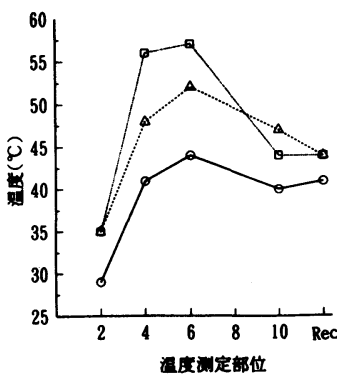

$200 \mathrm{ml} / \mathrm{min}$

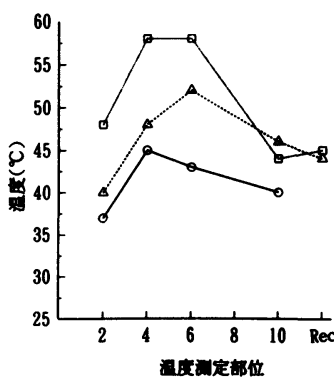

$\stackrel{15 \pi}{\ominus} \stackrel{30 \pi}{\square} \stackrel{50 \pi}{\square}$
ザー治療における前立腺組織内温度分布の報告はな

く, 本報告が正確な温度分布を測定した初めての報告 である。

まず, 冷水による前立腺組織冷却効果であるが, 図 3 において T2では流速の増加とともに温度が下降す る傾向を示し, T6では流速の増加によっても温度の下 降傾向はみられなかった，T4はこの中間に属した。つ まり冷水による前立腺組織冷却効果は尿道粘膜より 6 $\mathrm{mm}$ 以内であると考えられた。次に，レーザー・エネ
ルギーによる加温であるが，図 2 において T2から $\mathrm{T} 6$ までは出力の上昇にともなって温度上昇がみられる が，T10および TRecでは出力が上昇しても明らかな 温度上昇は認められなかった。つまりレーザー・エネ ルギーはそのほとんどが尿道粘膜より $10 \mathrm{~mm}$ 以内で吸 収され温度上昇に関与すると考えられた。

さらに, 前立腺組織内温度分布においては, 図 4 に おいて流速 $200 \mathrm{ml} / \mathrm{min}$, 出力 $30 \mathrm{~W}$ の条件でピーク温度 $\mathrm{T} 6$ が平均 $52^{\circ} \mathrm{C}$ となり $4 \sim 10 \mathrm{~mm}$ の温度が $45^{\circ} \mathrm{C}$ 以上とな 
る温度分布が得られた。前立腺における高温度治療の 可能性が示唆された。

Nissenkorn and Meshorer ${ }^{10)}$ は，犬 5 頭を用い RF 波による前立腺ハイパーサーミアにおける温度分布を 測定し, ピーク温度は前立腺尿道部 heat antenna の $44.6^{\circ} \mathrm{C}$ であり, $4{ }^{\circ} \mathrm{C} / \mathrm{cm}$ の温度匂配で組織内温度が下 降すると報告した。また, Astrahan 等 ${ }^{11}$ は 5 例の BPH 患者に対する microwaveによるハイパーサー ミアにおける温度分布を測定し, 前立腺部尿道温度は $47^{\circ} \mathrm{C}$ を越えず，温度匂配は $6 \sim 7^{\circ} \mathrm{C} / \mathrm{cm}$ であると報告し た. Nd：YAGレーザーは RF 波抢よび microwaveに 比べかなり短波長であるため，比較的浅部までしかエ ネルギーが到達しないためなのでろうが，バルーン・ レーザーの温度匂配は $10^{\circ} \mathrm{C} / \mathrm{cm}$ 以上と考えられた つまり，レーザーによる間接的な保温効果が加わった としても, RF 波および microwave のような緩やかな 温度匂配にはならないと考えられた。逆に考えれば， 温度匂配がやや急であるが故に，冷却を加えることに より他臟器まで障害を与えることなく前立腺組織内温 度を高温に保つことが可能であると結論できた。

\section{結 語}

雑種雄犬 4 頭を用いて, 前立腺バルーン・レーザー 治療における温度分布を検討した. 照射装置として $\mathrm{Nd}$ ：YAGレーザーに.よる，360度照射可能な灌流式 レーザー・バルーンを用い, 治療開始 $3 \sim 5$ 分後の温 度を計測した。この検討により次の結果を得た。

1. 膀胱頸部, 尿道括約筋部は極端な条件を除けば平 均 $42^{\circ} \mathrm{C}$ 以下に保たれた。

2. 前立腺組織の冷却効果の深達度は尿道粘膜より6 $\mathrm{mm}$ 以内と推定された.

3.レーザー・エネルギーは, そのほとんどが尿道粘 膜より $10 \mathrm{~mm}$ 以内で吸収され温度上昇に関与すると考 えられた。

4. 治療開始 $3 \sim 5$ 分後の前立腺内組織温度は $6 \mathrm{~mm}$ の深さがピークとなる一峰性の分布をとった. $30 \mathrm{~W}$, 流速 $200 \mathrm{ml} / \mathrm{min}$ の条件でピーク温度が平均 $52^{\circ} \mathrm{C}$ とな り, 4 $10 \mathrm{~mm}$ の温度が $45^{\circ} \mathrm{C}$ 以上となる温度分布が得ら れ, 前立腺高温度治療の可能性が示唆された。

\section{文献}

1) Holtgrewe, H.L., Mebust, W.K., Dowd, J.B., Cockett, A.T.K., Peters, P.C. and Proctor, C.: Transurethal prostatectomy: Practice aspects of the dominant operation in American urology. J. Urol., 141, 248-253, 1989.

2) Cotton, P.: Case for prostate therapy wanes despite more treatment options. J.A.M.A., 266, 459-460, 1991.

3) Devonec, M., Berger, N. and Perrin, P.: Transurethral microwave heating of the prostate -Or from hyperthermia to thermotherapy. J. Endourol., 5, 129-135, 1991.

4) Baeart, L., Ameye, F., Pike, M.C., Willemen, P., Astrahan, M.A. and Petrovich, Z.: Transurethral hyperthermia for benign prostatic hyperplasia patients with retention. J. Urol., 147, 1558-1561, 1992.

5) Yerushalmi, A., Singer, D., Katssnelson, R., Levy, E. and Shani, A. : Localized deep microwave hyperthermia in the treatment of benign prostatic hyperplasia: Long-term assessment. Br. J. Urol., 70, 178-182, 1992.

6) Roth, R.A. and Aretz, H.T.: Transurethral ultrasound-guided laser-induced prostatectomy (TULIP PROCEDURE): A canine prostate feasibilitry study. J. Urol., 146, 1128-1135, 1991.

7) Costello, A.J., Johnson, D.E. and Bolton, D.M. : $\mathrm{Nd}$ : YAG laser ablation of the prostate as a treatment for benign prostatic hypertrophy. Lasers Surg. Med., 12, 121-124, 1992.

8) Kurokawa, K., Suzuki, T., Yamanaka, H., Nakazato, M., Daikuzono, N. and Liong, M.L. : Endoscopic and ultrasonographic observation in the canine prostate before and after transurethral balloon lasertherapy (PROSTALASE ${ }^{\mathrm{TM}}$ ). J. Endourol.,投稿中

9) Suzuki, T., Kurokawa, K., Suzuki, K., Suzuki, K. and Hidetoshi, Y.: Thermal change in the canine prostate after transurethral balloon laser prostatectomy. Prostate.印刷中

10) Nissenkorn, I. and Meshorer, A.: Temperature measurements and histology of the canine prostate during transurethral hyperthermia. J. Urol., 149, 1613-1616, 1993.

11) Astrahan, M.A., Ameye, F., Oyen, R., Willemen, P., Baert, L. and Petrovich, Z.: Interstitial temperature measurements during transurethral microwave hyperthermia. J. Urol., 145, 304-308, 1991.

（1993年12月 8 日受付，1994年 5 月 10 日受理） 